Brief Communication

Comunicação Breve

Bruna Rainho Rocha ${ }^{1}$

Felipe Moreti ${ }^{1}$

Elisabeth Amin ${ }^{1}$

Glaucya Madazio ${ }^{1}$

Mara Behlau'

Keywords

Voice

Validation Studies

Protocols

Voice Quality

Music

Speech, Language and Hearing

Sciences

Questionnaires

Evaluation Studies

Descritores

Voz

Estudos de Validação

Protocolos

Qualidade da Voz

Música

Fonoaudiologia

Questionários

Estudos de Avaliação

Correspondence address:

Bruna Rainho Rocha

Rua Machado Bittencourt, 361/1.001,

Vila Mariana, São Paulo (SP), Brasil,

CEP: 04044-001.

E-mail: bruna.rocha41@gmail.com

Received: 09/19/2014

Accepted: 10/22/2014

\section{Cross-cultural adaptation of the Brazilian version of the protocol Evaluation of the Ability to Sing Easily}

\author{
Equivalência cultural da versão brasileira do protocolo \\ Evaluation of the Ability to Sing Easily
}

\begin{abstract}
Purpose: To present the cross-cultural equivalence of the Brazilian version of the Evaluation of the Ability to Sing Easily (EASE) protocol, through its cultural and linguistic adaptation. Methods: After the EASE was translated to Brazilian Portuguese, the back-translation into English was done. The items of the translated version were compared with the original instrument and the discrepancies were modified by consensus of a committee composed of five speech language pathologists. The Evaluation of the Ability to Sing Easily for Brazil (EASE-BR) has 22 questions with four alternatives: "no," "mildly," "moderately," and "extremely." The score is obtained by the simple sum of all answers. The three positive items $(6,12$, and 21$)$ require reverse score. For cultural equivalence, the EASE-BR was applied with 41 Brazilian singers, with an extra item in the answer key - "not applicable." The aim of this extra key was to identify issues that might not have been understood or were not appropriate for the target population and the Brazilian culture. Results: Of the 32 singers, 5 who were initially evaluated had difficulties to answer 3 of the 22 questions. Therefore, the adaptation of those sentences was necessary. Afterward, the modified EASE-BR was applied to nine singers, and no more cultural and/or conceptual barriers were found. Conclusion: Cultural equivalence was observed between EASE and its translated version to the Brazilian Portuguese, the EASE-BR. Validation of the EASE for Brazilian Portuguese is in progress.
\end{abstract}

\section{RESUMO}

Objetivo: Realizar a equivalência cultural da versão brasileira do protocolo Evaluation of the Ability to Sing Easily (EASE), por meio de sua adaptação cultural e linguística. Métodos: Após tradução do EASE para o Português brasileiro e retrotradução para o Inglês, realizou-se a comparação dos itens com o instrumento original, sendo as discrepâncias existentes modificadas por consenso por um comitê composto por cinco fonoaudiólogos, chegandose ao Evaluation of the Ability to Sing Easily para o Brasil (EASE-BR), com 22 questões e quatro alternativas na chave de resposta: "não", "um pouco", "moderadamente" e "muito". A pontuação é a soma simples de todas as respostas, sendo que os três itens com aspectos positivos (6, 12 e 21) exigem pontuação reversa. Para a equivalência cultural, o EASE-BR foi aplicado em um total de 41 cantores brasileiros, com acréscimo da opção "não aplicável" na chave de respostas, para identificação de questões não compreendidas ou não apropriadas para a população-alvo e a cultura brasileira. Resultados: Cinco dos 32 cantores inicialmente avaliados encontraram dificuldade para o preenchimento de três questões, sendo necessária adaptação da tradução das sentenças não compreendidas ou consideradas inapropriadas. O EASE-BR modificado foi então aplicado em mais nove cantores e não foram encontradas mais barreiras culturais e/ou conceituais. Conclusão: Foi verificada equivalência cultural entre o EASE e sua versão traduzida para o Português brasileiro, o EASE-BR. A validação do EASE para o Português brasileiro está em andamento, após a conclusão dessa etapa.

Study carried out at the Center of Voice Studies - CEV - São Paulo (SP), Brazil.

(1) Center of Voice Studies - CEV - São Paulo (SP), Brazil.

Conflict of interests: nothing to declare. 


\section{INTRODUCTION}

Voice self-assessment protocols have been developed and specified since the $1990 \mathrm{~s}^{(1)}$, and are considered as important tools to measure the knowledge of an individual about the impact of the problem in social and professional relationships ${ }^{(2)}$. Despite being frequently used, most protocols, and their respective translations, cultural adaptations ${ }^{(3)}$, and validation to Brazilian Portuguese ${ }^{(4-9)}$, are still addressed to specific conditions. Therefore, they are not adequate for individuals with healthy voices, such as voice professionals, who deserve specific evaluation ${ }^{(10-12)}$. To fill this gap, the protocol Evaluation of the Ability to Sing Easily (EASE) was created ${ }^{(13)}$ to assess the perception of the singers about the status of their singing voice after a performance, thus promoting the immediate overview about the use of voice.

The EASE was created in English, so, for it to be used in other languages, it must be translated and culturally adapted according to the international rules from the Scientific Advisory Committee of the Medical Outcome Trust ${ }^{(14)}$.

The objective of this study was to perform the cultural equivalence of the Brazilian version of the EASE protocol, through its cultural and linguistic adaptation.

\section{METHODS}

The study was approved by the research ethics committee of Hospital Municipal e Maternidade Escola Dr. Mário de Moraes (report no. 721.483 and CAAE: 32107014.2.0000.5454). All the participants signed the informed consent.

41 Active Brazilian singers participated in the study, without distinguishing musical style, gender, age, or socioeconomiccultural level.

The original version was translated to Brazilian Portuguese by two speech language pathologists who were fluent in the foreign language (translator 1, T1; translator 2, T2). These translations were superimposed, which resulted in the first Portuguese version (PV). A third speech language pathologist, who was also fluent in English, and had no access to the original version of the instrument and to the objectives of the study, back-translated it.

Translation and back-translation were compared between themselves and with the original instrument. The existing discrepancies were analyzed and discussed by a committee composed of five speech language pathologists specialized in voice, with proficiency in English and knowledge of specific vocabulary for the population of singers. The necessary changes were carried out by consensus and the final protocol was achieved. It is called Evaluation of the Ability to Sing Easily for Brazil (EASE-BR).

As in the original protocol, the EASE-BR remained with 22 questions and 4 alternatives to mark how often the described situation occurred: "no," "mildly," "moderately," and "extremely". Of the 22 questions, 19 were usual describers of fatigue and vocal limitations, and the other 3 were positive and new aspects in the literature. The score was a simple sum of the 19 negative items, being $0=$ no, $1=$ mildly, $2=$ moderately, and
$3=$ extremely, with the three positive items (questions 6,12 , and 21) added reversely, as follows: $3=$ no, $2=$ mildly, $1=$ moderately, and $0=$ extremely.

For cultural equivalence, the EASE-BR was applied among 41 Brazilian singers (32 in the first stage and 9 in the second stage), and the option "non-applicable" was added to identify questions that were not understood or inappropriate for the target population and the Brazilian culture.

\section{RESULTS}

In the first stage, 5 of the 32 singers who were initially assessed found difficulties to fill out three questions (items 3: "My voice is cracking and breaking"; 8: "My voice sounds tense"; and 21: "If I had to, I could sing again"). So, the committee of speech language pathologists modified sentences that were not understood or considered to be inappropriate. Item 8 was altered to "I feel my voice tense" after the consensus of the judge committee. Items 3 and 21, which were, respectively, modified to "My voice is failing and breaking" and "If I had to, I could sing again now," were changed after the target population did not understand it as it had been first translated. The modified EASE-BR was then applied to nine other singers who were vocally healthy, and cultural and/or conceptual barriers were not identified. The whole process of translation, semantic, and cultural equivalence of the EASE to Brazilian Portuguese is shown in Chart 1.

The final composition of the Brazilian version that was translated and culturally adapted from the EASE, called EASE-BR (Appendix 1), presents 22 items, just as the original protocol.

\section{DISCUSSION}

Obtaining cultural equivalence is the first stage to validate protocols, and it is essential so that no barriers remain between the instrument and its target population in different countries ${ }^{(14)}$. This stage has been successfully reached in validations of other protocols in Brazil ${ }^{(4-9)}$, which served as example and model for this project. In the case of the stage of adaptation of the EASE to Brazil, 3 of the 22 sentences had to be revised until the protocol could be accepted by the target population.

The EASE is a specific protocol for singers, developed to be sensitive to the vocal subtleties of this population ${ }^{(13)}$. After the conclusion of the process of translation and adaptation to Brazilian Portuguese, the process of validating the EASE-BR will take place. In this stage, the possibility to use it as an instrument of prevention and early detection of vocal problems will be assessed, considering the high demand of singers. Its use will be important, because most voice self-assessment protocols are addressed to specific conditions ${ }^{(4-9)}$ and are not adequate for individuals with healthy voices.

\section{CONCLUSION}

Cultural equivalence was observed between the EASE and its version translated to Brazilian Portuguese, the EASE-BR. The validation of EASE to Brazilian Portuguese is ongoing, after the conclusion of this stage. 
Chart 1. Process of translation and cultural adaptation of the protocol Evaluation of the Ability to Sing Easily (EASE) ${ }^{(13)}$ to Brazilian Portuguese

\begin{tabular}{|c|c|c|c|c|c|}
\hline Questions & $\begin{array}{l}\text { Original } \\
\text { version in } \\
\text { English }\end{array}$ & Translation to Brazilian Portuguese & $\begin{array}{l}\text { Back- } \\
\text { translation } \\
\text { of the PV to } \\
\text { English }\end{array}$ & $\begin{array}{c}\text { Committee of speech } \\
\text { language pathologists: } \\
\text { semantic and language } \\
\text { equivalence }\end{array}$ & $\begin{array}{l}\text { Committee of speech } \\
\text { language pathologists: } \\
\text { cultural and linguistic } \\
\text { equivalence }\end{array}$ \\
\hline 3 & $\begin{array}{l}\text { My voice } \\
\text { cracks and } \\
\text { breaks }\end{array}$ & $\begin{array}{l}\text { T1: Minha voz falha e quebra } \\
\text { T2: Minha voz está rachando e quebrando } \\
\text { PV: Minha voz está rachando e quebrando }\end{array}$ & $\begin{array}{l}\text { My voice } \\
\text { breaks }\end{array}$ & $\begin{array}{l}\text { Minha voz está rachando } \\
\text { e quebrando }\end{array}$ & $\begin{array}{l}\text { Minha voz está } \\
\text { falhando e quebrando }\end{array}$ \\
\hline 5 & $\begin{array}{l}\text { My voice is } \\
\text { breathy }\end{array}$ & $\begin{array}{l}\text { T1: Minha voz está soprosa } \\
\text { T2: Minha voz está soprosa/com ar/Estou } \\
\text { com ar na voz } \\
\text { PV: Estou com ar na voz }\end{array}$ & $\begin{array}{l}\text { My voice is } \\
\text { breathy }\end{array}$ & Estou com ar na voz & Estou com ar na voz \\
\hline 6 & $\begin{array}{l}\text { My singing } \\
\text { voice feels } \\
\text { good* }^{*}\end{array}$ & $\begin{array}{l}\text { T1: Minha voz cantada está boa } \\
\text { T2: Sinto minha voz cantada muito boa } \\
\text { PV: Minha voz cantada está boa }\end{array}$ & $\begin{array}{l}\text { My singing } \\
\text { voice is good }\end{array}$ & $\begin{array}{l}\text { Minha voz cantada } \\
\text { está boa }\end{array}$ & $\begin{array}{l}\text { Minha voz cantada } \\
\text { está boa* }\end{array}$ \\
\hline 7 & $\begin{array}{l}\text { The onsets } \\
\text { of my notes } \\
\text { are delayed or } \\
\text { breathy }\end{array}$ & $\begin{array}{l}\text { T1: O ataque das notas está atrasado ou } \\
\text { soproso } \\
\text { T2: Sinto dificuldade para iniciar o som, } \\
\text { que demora a sair ou sai soproso/com ar } \\
\text { PV: O ataque das notas está atrasado ou com ar }\end{array}$ & $\begin{array}{l}\text { The beginning } \\
\text { of the notes } \\
\text { are late or } \\
\text { breathy }\end{array}$ & $\begin{array}{l}\text { O ataque das notas está } \\
\text { atrasado ou com ar }\end{array}$ & $\begin{array}{l}\text { O ataque das notas } \\
\text { está atrasado ou com ar }\end{array}$ \\
\hline 10 & $\begin{array}{l}\text { I am having } \\
\text { difficulty with } \\
\text { my breath for } \\
\text { long phrases }\end{array}$ & $\begin{array}{l}\text { T1: Estou tendo dificuldade com a } \\
\text { respiração nas frases longas } \\
\text { T2: Estou com dificuldades respiratórias } \\
\text { nas frases longas/Não consigo sustentar o } \\
\text { ar nas frases longas } \\
\text { PV: Estou com dificuldade de controlar o ar } \\
\text { nas frases longas }\end{array}$ & $\begin{array}{l}\text { It is hard to } \\
\text { control the } \\
\text { air on long } \\
\text { phrases }\end{array}$ & $\begin{array}{l}\text { Estou com dificuldade de } \\
\text { controlar o ar nas frases } \\
\text { longas }\end{array}$ & $\begin{array}{l}\text { Estou com dificuldade } \\
\text { de controlar o ar nas } \\
\text { frases longas }\end{array}$ \\
\hline 11 & $\begin{array}{l}\text { My top notes } \\
\text { are breathy }\end{array}$ & $\begin{array}{l}\text { T1: Minhas notas agudas estão soprosas } \\
\text { T2: Minhas notas agudas estão soprosas/ } \\
\text { estão com ar } \\
\text { PV: Minhas notas agudas têm ar }\end{array}$ & $\begin{array}{l}\text { My high } \\
\text { pitched notes } \\
\text { are breathy }\end{array}$ & $\begin{array}{l}\text { Minhas notas agudas } \\
\text { têm ar }\end{array}$ & $\begin{array}{l}\text { Minhas notas agudas } \\
\text { têm ar }\end{array}$ \\
\hline 12 & $\begin{array}{l}\text { My voice } \\
\text { sounds rich } \\
\text { and resonant* }\end{array}$ & $\begin{array}{l}\text { T1: Minha voz está cheia e ressoante } \\
\text { T2: Minha voz sai encorpada e ressoante } \\
\text { PV: Minha voz soa cheia e ressoante }\end{array}$ & $\begin{array}{l}\text { My voice } \\
\text { sounds filled } \\
\text { and resonant }\end{array}$ & $\begin{array}{l}\text { Minha voz soa cheia e } \\
\text { ressoante }\end{array}$ & $\begin{array}{l}\text { Minha voz soa cheia e } \\
\text { ressoante }^{*}\end{array}$ \\
\hline 13 & $\begin{array}{l}\text { My voice is } \\
\text { cutting out on } \\
\text { some notes }\end{array}$ & $\begin{array}{l}\text { T1: Minha voz está sumindo em algumas notas } \\
\text { T2: Minha voz está sumindo em algumas } \\
\text { notas/O som da minha voz "corta"de } \\
\text { repente em determinadas notas } \\
\text { PV: Minha voz está falhando em algumas notas }\end{array}$ & $\begin{array}{l}\text { My voice is } \\
\text { breaking at } \\
\text { some notes }\end{array}$ & $\begin{array}{l}\text { Minha voz está falhando } \\
\text { em algumas notas }\end{array}$ & $\begin{array}{l}\text { Minha voz está } \\
\text { falhando em algumas } \\
\text { notas }\end{array}$ \\
\hline
\end{tabular}


Chart 1. Continuation

\begin{tabular}{|c|c|c|c|c|c|}
\hline Questions & $\begin{array}{l}\text { Original } \\
\text { version in } \\
\text { English }\end{array}$ & Translation to Brazilian Portuguese & $\begin{array}{l}\text { Back- } \\
\text { translation } \\
\text { of the PV to } \\
\text { English }\end{array}$ & $\begin{array}{c}\text { Committee of speech } \\
\text { language pathologists: } \\
\text { semantic and language } \\
\text { equivalence } \\
\end{array}$ & $\begin{array}{c}\text { Committee of speech } \\
\text { language pathologists: } \\
\text { cultural and linguistic } \\
\text { equivalence }\end{array}$ \\
\hline 14 & $\begin{array}{l}\text { I am having } \\
\text { difficulty } \\
\text { singing softly }\end{array}$ & $\begin{array}{l}\text { T1: Estou com dificuldade de cantar } \\
\text { piano (suave) } \\
\text { T2: Estou tendo dificuldades para cantar } \\
\text { suave ("piano"?) } \\
\text { PV: Estou com dificuldades para cantar } \\
\text { suave, piano }\end{array}$ & $\begin{array}{l}\text { l'm having } \\
\text { trouble to sing } \\
\text { piano/sing } \\
\text { soft }\end{array}$ & $\begin{array}{l}\text { Estou com dificuldades } \\
\text { para cantar suave, piano }\end{array}$ & $\begin{array}{l}\text { Estou com dificuldades } \\
\text { para cantar suave, } \\
\text { piano }\end{array}$ \\
\hline 15 & $\begin{array}{l}\text { My voice is } \\
\text { tired }\end{array}$ & $\begin{array}{l}\text { T1: Minha voz está cansada } \\
\text { T2: Minha voz está cansada } \\
\text { PV: Minha voz está cansada }\end{array}$ & $\begin{array}{l}\text { My voice is } \\
\text { tired }\end{array}$ & Minha voz está cansada & $\begin{array}{l}\text { Minha voz está } \\
\text { cansada }\end{array}$ \\
\hline 16 & $\begin{array}{l}\text { I am having } \\
\text { difficulty } \\
\text { changing } \\
\text { registers }\end{array}$ & $\begin{array}{l}\text { T1: Estou tendo dificuldades em mudar } \\
\text { registros } \\
\text { T2: Estou tendo dificuldades para mudar } \\
\text { registros } \\
\text { PV: Estou com dificuldades para passar } \\
\text { de registro }\end{array}$ & $\begin{array}{l}\text { I'm having } \\
\text { trouble to shift } \\
\text { registers }\end{array}$ & $\begin{array}{l}\text { Estou com dificuldades } \\
\text { para passar de registro }\end{array}$ & $\begin{array}{l}\text { Estou com dificuldades } \\
\text { para passar de registro }\end{array}$ \\
\hline 17 & $\begin{array}{l}\text { I am having } \\
\text { difficulty with } \\
\text { my high notes }\end{array}$ & $\begin{array}{l}\text { T1: Estou tendo dificuldades com as } \\
\text { notas agudas } \\
\text { T2: Estou tendo dificuldades com as } \\
\text { notas agudas } \\
\text { PV: Estou com dificuldades nas notas } \\
\text { agudas }\end{array}$ & $\begin{array}{l}\text { l'm having } \\
\text { trouble to } \\
\text { produce high } \\
\text { pitch notes }\end{array}$ & $\begin{array}{l}\text { Estou com dificuldades } \\
\text { nas notas agudas }\end{array}$ & $\begin{array}{l}\text { Estou com dificuldades } \\
\text { nas notas agudas }\end{array}$ \\
\hline 18 & $\begin{array}{l}\text { Singing feels } \\
\text { like hard work }\end{array}$ & $\begin{array}{l}\text { T1: Está difícil cantar } \\
\text { T2: Sinto que faço muito esforço para } \\
\text { conseguir cantar } \\
\text { PV: Sinto que estou fazendo esforço } \\
\text { para cantar }\end{array}$ & $\begin{array}{l}\text { I have to } \\
\text { struggle to } \\
\text { sing }\end{array}$ & $\begin{array}{l}\text { Sinto que estou fazendo } \\
\text { esforço para cantar }\end{array}$ & $\begin{array}{l}\text { Sinto que estou } \\
\text { fazendo esforço para } \\
\text { cantar }\end{array}$ \\
\hline 19 & $\begin{array}{l}\text { I am having } \\
\text { difficulty } \\
\text { projecting my } \\
\text { voice }\end{array}$ & $\begin{array}{l}\text { T1: Estou com dificuldade de projetar } \\
\text { minha voz } \\
\text { T2: Estou tendo dificuldades para } \\
\text { projetar a voz } \\
\text { PV: Estou com dificuldades para projetar } \\
\text { a voz }\end{array}$ & $\begin{array}{l}\text { I'm having } \\
\text { trouble on } \\
\text { my vocal } \\
\text { projection }\end{array}$ & $\begin{array}{l}\text { Estou com dificuldades } \\
\text { para projetar a voz }\end{array}$ & $\begin{array}{l}\text { Estou com dificuldades } \\
\text { para projetar a voz }\end{array}$ \\
\hline 20 & $\begin{array}{l}\text { I am } \\
\text { concerned } \\
\text { about my } \\
\text { voice }\end{array}$ & $\begin{array}{l}\text { T1: Estou preocupado com a minha voz } \\
\text { T2: A minha voz me preocupa } \\
\text { PV: Estou preocupado com a minha voz }\end{array}$ & $\begin{array}{l}\text { I am worried } \\
\text { about my } \\
\text { voice }\end{array}$ & $\begin{array}{l}\text { Estou preocupado com a } \\
\text { minha voz }\end{array}$ & $\begin{array}{l}\text { Estou preocupado com } \\
\text { a minha voz }\end{array}$ \\
\hline 21 & $\begin{array}{l}\text { My voice } \\
\text { feels ready for } \\
\text { performance } \\
\text { if required* }\end{array}$ & $\begin{array}{l}\text { T1: Minha voz está pronta para uma } \\
\text { apresentação, se for preciso } \\
\text { T2: Se fosse preciso, minha voz estaria } \\
\text { pronta para cantar novamente } \\
\text { PV: Se fosse preciso, eu poderia cantar } \\
\text { novamente }\end{array}$ & $\begin{array}{l}\text { If I had to, I } \\
\text { could sing } \\
\text { again }\end{array}$ & $\begin{array}{l}\text { Se fosse preciso, eu } \\
\text { poderia cantar novamente }\end{array}$ & $\begin{array}{l}\text { Se fosse preciso, } \\
\text { eu poderia cantar } \\
\text { novamente agora* }\end{array}$ \\
\hline 22 & $\begin{array}{l}\text { I am having } \\
\text { difficulty } \\
\text { sustaining } \\
\text { long notes }\end{array}$ & $\begin{array}{l}\text { T1: Estou tendo dificuldade em sustentar } \\
\text { notas agudas } \\
\text { T2: Estou tendo dificuldades para sustentar } \\
\text { notas longas } \\
\text { PV: Estou tendo dificuldades para sustentar } \\
\text { notas longas }\end{array}$ & $\begin{array}{l}\text { I'm having } \\
\text { trouble to } \\
\text { sustain a long } \\
\text { note }\end{array}$ & $\begin{array}{l}\text { Estou tendo dificuldades } \\
\text { para sustentar notas } \\
\text { longas }\end{array}$ & $\begin{array}{l}\text { Estou tendo } \\
\text { dificuldades para } \\
\text { sustentar notas longas }\end{array}$ \\
\hline
\end{tabular}

*Items with positive aspects and reverse score

Caption: T1 = English-Portuguese translator number 1; T2 = English-Portuguese translator number 2; PV = Portuguese version of the compilation of translations T1 + T2 
*BRR was in charge of study conception, data collection, tabulation and analysis, and the elaboration of the manuscript; FM was responsible for the study conception, data collection, and analysis and revision of the manuscript; EA and GM were in charge of study conception, data analysis, and revision of the manuscript; $M B$ was responsible for the study proposal and conception, data analysis, and final revision of the manuscript.

\section{REFERENCES}

1. Colton RH, Casper JK, Leonard R. Anamnese, exames e avaliações. In: Colton RH, Casper JK, Leonard R. Compreendendo os problemas da voz: uma perspectiva fisiológica no diagnóstico e tratamento das disfonias. $3^{\mathrm{a}}$ edição. Rio de Janeiro: Revinter; 2010. p. 195-251.

2. World Health Organization. WHOQOL. Measuring Quality of Life. The World Health Organization Quality of Life Instruments (THE WHOQOL-100 AND THE WHOQOL-BREF). Geneva: WHO; 1997.

3. Moreti F, Zambon F, Oliveira G, Behlau M. Cross-cultural adaptation of the Brazilian version of the Voice Symptom Scale: VoiSS. J Soc Bras Fonoaudiol. 2011;23(4):398-400.

4. Gasparini G, Behlau M. Quality of Life: validation of the Brazilian version of the Voice-Related Quality-of-Life (V-RQOL) Measure. J Voice. 2009;23(1):76-81.

5. Behlau M, Alves dos Santos LM, Oliveira G. Cross-cultural adaptation and validation of the voice handicap index into Brazilian Portuguese. J Voice. 2011;25(3):354-9.
6. Paulinelli BR, Gama AC, Behlau M. Validation of the Vocal Performance Questionnaire in Brazil. Rev Soc Bras Fonoaudiol. 2012;17(1):85-91.

7. Costa T, Oliveira G, Behlau M. Validation of the Voice Handicap Index: 10 (VHI-10) to the Brazilian Portuguese. CoDAS. 2013;25(5):482-5.

8. Ricarte A, Oliveira G, Behlau M. Validation of the Voice Activity and Participation Profile protocol in Brazil. CoDAS. 2013;25(3):242-9.

9. Moreti F, Zambon F, Oliveira G, Behlau M. Cross-cultural adaptation, validation, and cutoff values of the Brazilian version of the Voice Symptom Scale-VoiSS. J Voice. 2014;28(4):458-68.

10. Behlau M, Zambon F, Madazio G. Managing dysphonia in occupational voice users. Curr Opin Otolaryngol Head Neck Surg. 2014;22(3):188-94.

11. Warhurst S, McCabe P, Madill C. What makes a good voice for radio: perceptions of radio employers and educators. J Voice. 2013;27(2):217-24.

12. Paoliello K, Oliveira G, Behlau M. Singing voice handicap mapped by different self-assessment instruments. CoDAS. 2013;25(5):463-8.

13. Phyland DJ, Pallant JF, Benninger MS, Thibeault SL, Greenwood KM, Smith JA, et al. Development and preliminary validation of the EASE: a tool to measure perceived singing voice function. J Voice. 2013;27(4):454-62.

14. Aaronson N, Alonso J, Burnam A, Lohr KN, Patrick DL, Perrin E, et al. Assessing health status and quality-of-life instruments: attributes and review criteria. Qual Life Res. 2002;11(3):193-205.

Appendix 1. Translated and culturally adapted version of the protocol Evaluation of the Ability to Sing Easily (EASE)(13), called Evaluation of the Ability to Sing Easily for Brazil (EASE-BR)

\begin{tabular}{|c|c|c|c|c|c|}
\hline \multicolumn{6}{|c|}{$\begin{array}{l}\text { Por favor, responda às seguintes perguntas com base em como você sente a sua voz ou em como ela soa agora. Se ela tem variado ao longo } \\
\text { do dia, basta escolher a resposta que mais combina com como sua voz está agora. }\end{array}$} \\
\hline 1 & Minha voz está rouca & Não & Um pouco & Moderadamente & Muito \\
\hline 2 & Minha garganta está seca/raspando & Não & Um pouco & Moderadamente & Muito \\
\hline 3 & Minha voz está falhando e quebrando & Não & Um pouco & Moderadamente & Muito \\
\hline 4 & Sinto os músculos da garganta sobrecarregados & Não & Um pouco & Moderadamente & Muito \\
\hline 5 & Estou com ar na voz & Não & Um pouco & Moderadamente & Muito \\
\hline 6 & Minha voz cantada está boa* & Não & Um pouco & Moderadamente & Muito \\
\hline 7 & O ataque das notas está atrasado ou com ar & Não & Um pouco & Moderadamente & Muito \\
\hline 8 & Sinto minha voz tensa & Não & Um pouco & Moderadamente & Muito \\
\hline 9 & Minha voz me preocupa & Não & Um pouco & Moderadamente & Muito \\
\hline 10 & Estou com dificuldade de controlar o ar nas frases longas & Não & Um pouco & Moderadamente & Muito \\
\hline 11 & Minhas notas agudas têm ar & Não & Um pouco & Moderadamente & Muito \\
\hline 12 & Minha voz soa cheia e ressoante* & Não & Um pouco & Moderadamente & Muito \\
\hline 13 & Minha voz está falhando em algumas notas & Não & Um pouco & Moderadamente & Muito \\
\hline 14 & Estou com dificuldades para cantar suave, piano & Não & Um pouco & Moderadamente & Muito \\
\hline 15 & Minha voz está cansada & Não & Um pouco & Moderadamente & Muito \\
\hline 16 & Estou com dificuldades para passar de registro & Não & Um pouco & Moderadamente & Muito \\
\hline 17 & Estou com dificuldades nas notas agudas & Não & Um pouco & Moderadamente & Muito \\
\hline 18 & Sinto que estou fazendo esforço para cantar & Não & Um pouco & Moderadamente & Muito \\
\hline 19 & Estou com dificuldades para projetar a voz & Não & Um pouco & Moderadamente & Muito \\
\hline 20 & Estou preocupado com a minha voz & Não & Um pouco & Moderadamente & Muito \\
\hline 21 & Se fosse preciso, eu poderia cantar novamente agora* & Não & Um pouco & Moderadamente & Muito \\
\hline 22 & Estou tendo dificuldades para sustentar notas longas & Não & Um pouco & Moderadamente & Muito \\
\hline
\end{tabular}

*Itens com aspectos positivos e pontuação reversa 